\title{
Ambivalent colonal relations in octavia butler's wild seed
}

\author{
Thamer Amer Jubouri Al Ogaili ${ }^{1}$ \\ Ruzbeh Babaee ${ }^{2}$
}

\begin{abstract}
This article explores postcolonial powers of ambivalence in Octavia Butler's Wild Seed (1980). It will offer an in-depth analysis of the thematic and ideological characteristics of selected work. We will mainly focus on the theme of the mutual relationship between the colonized and the colonizer in the novel. This relationship is specified to the concept of ambivalence that incarnates the dual, yet, uncontrolled relationship between the colonized and the colonizer. Nevertheless, the colonized considers the colonizer as oppressive but an envious power; and the colonizer judges the colonized as inferior but indigenous. The colonial relationship will also be revealed by using the concept of self-other. Such concept scrutinizes the way the colonized and the colonizer perceive and resist each other. Thus, the study's main focus point is the power relationship developed in the light of colonial ambivalence and self-other continuum. The colonial characteristics of this study offer a new interpretation of the colonial relationship depicted in the novel. Accordingly, the ambivalent relationship between the colonized and the colonizer will be equal (i.e. both of them have positive and negative attributes). This interpretation paves the way for other discourse studies interested in the depiction of the colonized and the colonizer relationship in postcolonial literature in general, and in Butler's fiction in particular.
\end{abstract}

Keywords: Ambivalence; Hegemony; Postcolonialism; Self-Other Relationship; Butler

\section{Introduction}

Octavia Butler's Wild Seed (1980) is a postcolonial work addressing the suppressed voices of the colonized people. It calls for a proper and comprehensive appreciation of the colonized people, especially the black Africans. The novel has a latent meaning reflecting Butler's critique of the contemporary colonial agendas which represent the blacks in an inferior position. It is the inherent quality of the novel which draws attention to its status as a colonial work set within the limits of colonial powers. Colonialism, and its tragic sequences, brought about distinctive identities and social classes. These classes go along with the common trend of colonialism and its plans. In this way, the suppressed vices could not find an outlet for their sufferings; and they struggled for equality and fair rights to rescue them form such position. Wild Seed, thus, exposes the plights of those sufferings and has a highly obtrusive example of liberating the suppressed black voices midst the colonial waves of the time. It holds Butler's visionary perspective on the transient position of the exploited blacks at the hands of the whites' suppression. As such, the critical insights of the

\footnotetext{
1 MA. of World Literature, University Putra Malaysia, Faculty of Modern Languages and Communication, English Department, thamera68@gmail.com

${ }^{2}$ Senior lecturer of English Literature, University Putra Malaysia, Faculty of Modern Languages and Communication, English Department, ruzbeh babaei@upm.edu.my
} 
Ogaili, T. A. J. A., \& Babaee, R. (2016). Ambivalent colonal relations in octavia butler's wild seed. International Journal of Human Sciences, 13(1), 22-31. doi:10.14687/ijhs.v13i1.3458

novel convey an earnest human volition questioning the possibility of this suppression's end. The novel's sober subtlety disposition renders it a real treatment of colonial suppression and the way to its transience. Being that so, it has organized thematic concerns which oppose colonial tyranny in all its aspects (Hoogvelt 53).

This study, therefore, will examine the depiction of the colonial suppression in Wild Seed. The study's main focus will be on the self-other relationship between the blacks and the whites. This relationship will be analyzed by applying Edward Said's concept of self-other relationship. It will be further elaborated by using the concept of hegemony which sheds light on the colonial superiority over the colonized blacks in the novel. Homi Bhabha's concept of ambivalence will also be applied to explore the equal relationship between the blacks and the whites characterized in the novel.

\section{Self-Other Relationship}

Wild Seed tells the story of Anyanwu, the immortal female who lives in West-Africa. Doro, who is another immortal character, finds Anyanwu and they become friends. They gradually become more familiar with each other, and do not feat each other as before. They intend to procreate each other but in a usual way. They avoid death by jumping from human body to another body to keep their immorality. Anyanwu wants to breed children to keep her posterity as a means of avoiding death, but Doro promises her to be alive even though she does not give birth to children. Therefore, Doro's supernatural powers make him create children for Anyanwu. He, then, makes some efforts to force her marry Isaac when they enter Doro's colony. Anyanwu does not cope with the life in the colony because of the cultural difference between her traditions and the colony's cultural tradition. Isaac dies, and Anyanwu becomes happy because she will be free from Doro's suppression. She hides from Doro by changing herself into a dolphin for years. After that, she establishes her own colony, but Doro finds her again and takes her with her children and enslaves them. At the end of the story, both Doro and Anyanwu become inseparable and need each other for the rest of their lives.

In Wild Seed, the colonial powers are exemplified in the characters of Anyanwu and Doro: "Anyanwu watched carefully as the white woman placed first a clean cloth, then dishes and utensils on the long, narrow table at which the household was to eat. Anyanwu was glad that "some of the food and the white people's ways of eating it were familiar to her from the ship" (75). Additionally, Anyanwu represents on aspect of this powerful relationship: "She could sit down and have a meal without seeming utterly ignorant. She could not have cooked the meal, but that would come, too, in time. She would learn. For now, she merely observed and allowed the interesting smells to intensify her hunger. Hunger was familiar and good" (75). The hunt here stands for colonialism: "It kept her from staring too much at the white woman, kept her from concentrating on her own nervousness and uncertainty in the new surroundings, kept her attention on the soup, thick with meat and vegetables, and the roast deer flesh—venison, the white woman had called it—and a huge fowl —a turkey" (75). Anyanwu cloths, for example, are an indication of colonial influence upon the colonized: "Anyanwu repeated the words to herself, reassured that they had become part of her vocabulary. New words, new ways, new foods, new clothing... She was glad of the cumbersome clothing, though, finally. It made her look more like the other women, black and white, whom she had seen in the village, and that was important" (75).

Such kind of colonial transformation is set within the limits of self-other relationship because "colonial discourse analysis theory is its dependence on the discursive coherence of colonial relations; through which the self/other relation is introduced as fixed binaries. The construction of the colonial subject is depicted through a discursive essentialist mode of representation whose basic features are stability, autonomy and coherence" (Ahmad 62). This coherence is "the split between the two primary entities" (27). It also "maintains the differences between colonized culture" (Said). 
Ogaili, T. A. J. A., \& Babaee, R. (2016). Ambivalent colonal relations in octavia butler's wild seed. International Journal of Human Sciences, 13(1), 22-31. doi:10.14687/ijhs.v13i1.3458

Edward Said, in Orientalism (1978), claims that the "self and other, the colonized/colonizer, that the colonial culture maintains in a discourse of power relations, construct a web of racial and cultural stereotypes, power relations and 'dehumanizing ideology' that dominate the colonizer and the colonized in the colonial world" (27). This relation inherently "depends largely for its strategy on this primary division of reality, it is intended by the colonial suppression to go beyond this colonial discourse. The discourse of colonial powers does not place the self-other relation in a whole series of unified and sustained relationships with the colonial premise, the colonial influence upon societies" (27).

This relationship is represented in Wild Seed in terms of the blacks and the whites relations: "The portrait was a black madonna and child right down to Anyanwu's too-clear, innocent-seeming eyes. Strangers were moved to comment on the likeness. Some were appreciative, looking at the still handsome Anyanwu-she kept herself looking well for Isaac even as she aged herself along with him" (96). The other black people are also depicted in this relationship: "Others were deeply offended, believing that someone actually had tried to portray the Virgin and Child as 'black savages.' Race prejudice was growing in the colonies—even in this formerly Dutch colony where things had once been so casual. Earlier in the year, there had been mass executions at New York City" (96). These savage people are the "other" blacks: "Someone had been setting fires and the whites decided it must be the blacks. On little or no evidence, thirty-one blacks were killedthirteen of them burned at the stake. Doro was beginning to worry about this upriver town. Of all his English colonial settlements, only in this one did his blacks not have the protection of powerful white owners. How soon before whites from elsewhere began to see them as fair game" (96).

Doro's colony is an incarnation of self-other relationship since it "offers an interesting instance of the interrelation between colonizer, colonized, society and, history, the personal and the textual. These dichotomies which have become part of the common colonial historical discourse, the very similar colonial discourse" (Sheffer 46). It is, thus, the "magnificently destabilized in the fragmented self of the persona in the narrative. Moreover, the complicated roles played by the other colonizer in fictional discourses which connects colonialism with the ideologies and cultures of both the self and other. History, politics, psychology and power relations which are all matters of significant relevance in colonial discourses are incorporated in the suppression discourses of colonialism" (46). This historical dimension "produces a narrative that reacts conversely to the colonial monolithic discourse of power relations. The narrator exhibits a marvelous capacity to be inside and outside the colonial culture dominant in these discourses; they could transcend the deeply troubling and essentialized self/other approach to colonial relations that often entrap it" (Williams 73).

In Wild Seed, Anyanwu is influenced by Doro's colonial suppression: “'Even so.' Anyanwu stared up at the solemn young woman, remembering that lovely, fearful courting. They had been as fearful of marrying as they had been of losing each other. 'She thought at first that there could be no children, and that saddened her because she had always wanted children" (146). Anyanwu and Doro relations go along with the self-other dichotomy: "Then she realized that I could give her girls. It took her a long time to understand all that I could do. But she thought the children would be black and people would say she had been with a slave. White men leave brown children all about, but a white woman who does this becomes almost an animal in the eyes of other whites"' (146).

More significantly, the self-other relationship is "a model in which suppression and colonialism can be both incorporated in colonial discourses where transformed identities function with a multiplicity of roles and categories in a suppressive-like colonial discourse, the fact that challenges traditional postcolonial representations of the colonized subject/self' (Said 27). By the same token, colonial suppression and "all throughout colonial practices, there is a common consciousness in 
Ogaili, T. A. J. A., \& Babaee, R. (2016). Ambivalent colonal relations in octavia butler's wild seed. International Journal of Human Sciences, 13(1), 22-31. doi:10.14687/ijhs.v13i1.3458

which an outsider 'other' can interact with the self on a major premise in colonial discourses, this hegemonic relation is broken in colonial subjective reflections on its own realities as formed and shaped in different and uncompromising suppression" (Lommba 85). In this way, colonial suppression "attempts to establish a connection between the subjective colonial identity and its political and social realities, which is one more way to say that they instrumentalize colonialism and exploitation for developing colonial discourses" (85). Furthermore, they "realize the suppression intention of these colonail discourses of the colonizer self in the narrative to act in contrary to some of the assumptions outlined in the Post-colonial theory. The analysis of the suppressive self in colonialism holds the potential for creative and constructive critique of the suppressed and marginal role of 'the other' in the history of colonialism and post-colonialism" (Lommba 86).

Here, suppression culminates in the linguistic changes in the charters of Wild Seed. These characters speak another language just like their colonizers: "An old woman came up to her-a white woman, withered and gray, Luisa, who did what sewing she could for her keep. She was one of five white people on the place" (148). It is the whites who make them change their language: "There could have been many more whites, fitting in very comfortably, but the race-conscious culture made that dangerous. The four younger whites tried to lessen the danger by telling people they were octoroons. Luisa was a Creole-a French-Spanish mixture-and too old to care who knew it" (148).

In postcolonial theory, the linguistic change in the colonized language is "closely related to the concept of the Self and the Other because as it points out in the comprehensive definition of colonialism, it makes a distinction between the colonized, i.e. self and the colonizer, i.e. the Other, since the analysis of the relationship of the 'self' and the 'other' is at the heart of Postcolonialism and many define Postcolonialism in terms of the relationship of the self and the Other" (Wisker 48). In fact, it is the postcolonial suppression which "is based on binary oppositions, a hierarchy in which one is privileged and the other is unprivileged. Binarism ranges from general binaries such as light/dark, white/black to some more complicated and culturally weighted as man/woman, the colonizer/ the colonized and in the case under consideration the self/other" (48). This binarism is the identification of self-other relationship in which "this binary opposition takes a prominent place within feminist, psychoanalysis, postcolonial and queer theory" (48). Consequently, the colonial "outcome of suppression and exploitation is the building on a binary opposition between the self and the other. The other is imposed on everything in the life of the self which is not, exotic, alien, dangerous, unreliable, to be tamed, exhibited, or a threat, but a suppressive other" (Ashcroft 39).

In Wild Seed the colonial binarism is the relationship between the blacks and the whites in Doro's colony: "He [Doro] would laugh and promise her nothing. Who knew what punishment he might have to inflict, what madman he might have to subdue, what stupid, stubborn politician, businessman, planter, or other fool he might have to remove? Also, wearing a black body in country where blacks were under constant obligation to prove they had rights to even limited freedom was a hindrance" (177). Doro practices colonial suppression over his colony's people: "He traveled with one of his older white sons, Frank Winston, whose fine old Virginia family had belonged to Doro since Doro brought it from England 135 years before. The man could be as distinguished and aristocratic or as timid and naive as he chose to be, as Doro ordered him to be" (177). He suppresses them to make them breed more children for his colony: "He had no inborn strangeness great enough to qualify him as good breeding stock. He was simply the best actor, the best liar Doro knew. People believed what he told them even when he grew expansive and outrageous, when he said Doro was an African prince mistakenly enslaved, but now freed to return to his homeland and take the word of God back to his heathen people" (177). 
Ogaili, T. A. J. A., \& Babaee, R. (2016). Ambivalent colonal relations in octavia butler's wild seed. International Journal of Human Sciences, 13(1), 22-31. doi:10.14687/ijhs.v13i1.3458

Doro's powerful suppression creates a "controversy about the postcolonial discourse which begins with the term of re-presentation which gives the colonial power as a 'genuine creator' whose lifegiving power represents, animates, constitutes, the otherwise silent and dangerous space beyond familiar boundaries (italics in original)" (Boehme 57). This "representation is so powerful which brought the concept of the other colonizer, first of all in colonial discourses, then suprressive consciousness, and later colonial empire" (203). Here, "the effect of this representation is the creation of binary opposition of the self and other which posits the former in the privileged position that permits himself to define, describe and articulate the colonized self as it is, and the former in the position of a silent, disabled object of study. The self continues to make any distinction between representation and misrepresentation and the difference is matter of a colonial degree" (65). The real colonial distinction "is whether indeed there can be a true representation of anything, or whether any and all representations, because they are representations, are embedded first in the language and then in the culture, institutions, and political ambience of the representer. If the latter alternative is the suppressive one ( as I believe it is)" (Moore-Gilbert 72), then it is prepared to accept the fact that a representation is the suppression implicated, intertwined, embedded, interwoven with a great many things besides the 'truth', which is itself a representation of colonial reality" (72). In Wild Seed, the representation of this reality originates in Doro's suppression of Anyanwu and other characters. This relation is represented by the suppressive authority used by Doro to subjugate his colony's people. His suppression is sustained by the power of hegemony which will be elaborated in the following section.

\section{Hegemony}

Hegemony is a colonial term used to qualify a "sufficient explanation of colonial powers to dispel the hegemonic nature of suppressed voice itself. Suppressing of other nations is one former metropolitan power instead of another automatically relocates the role of postcolonial literature in the global market place" (Laitin 69). This is because "the historical traces that connote colonial relations not only influence but also determine the position that new cultural productions acquire in an age of late colonialism. Colonialism has, has, become a relation in itself and it marks the positioning of literature along the diffused and complex lines of colonial dynamics" (69). It produces a "contact zone between society and its representation through literature. In this literature theories and politics meet to defy and subvert previous colonial hierarchies. Post- colonial literature thus constitutes a fruitful and contentious field of studies, which is not devoid of internal frictions or paradoxes of hegemony" (71).

In Wild Seed, Doro embodies the hegemonic paradoxes: "He had been watching her, looking at her eyes with a curiosity that most people tried to hide from her. People said her eyes were like babies' eyes - the whites too white, the browns too deep and clear. No adult, and certainly no old woman should have such eyes, they said. And they avoided her gaze" (5). Moreover, Doro's eyes were very ordinary, but he could stare at her as children stared. He had no fear, and probably no shame" (5). Doro's fearless state is a reflection of his powerful hegemony: "I came to this territory last about three hundred years ago," he said. "I was looking for a group of my people who had strayed, but they were killed before I found them. Your people were not here then, and you had not been born. I know that because your difference did not call me. I think you are the fruit of my people's passing by yours, though"” (5).

Hegemony is suppressive authority; whereby "the colonial anxiety that the postcolonial paradigm narrows down intellectual investigations not only around the rubric of colonial history but - even more limiting - around the imperial canon. This has been amply demonstrated by the many studies focusing on British India and on "the empire writing back" from India as the ad hoc peripheral location" (Kapoor 83). Hegemony is "the privileging of the colonail context, whereby postcolonialism reproduces one of the main paradoxes whose abolition was at the center of the 
Ogaili, T. A. J. A., \& Babaee, R. (2016). Ambivalent colonal relations in octavia butler's wild seed. International Journal of Human Sciences, 13(1), 22-31. doi:10.14687/ijhs.v13i1.3458

postcolonial agenda" (83). This colonial agenda incorporates "the politics of institutionalization of the imperial language through a systematic suppressive system, it is no coincidence that the strongest response comes from the hegemonic powers which includes the colonial suppression and its negative influence upon the colonized, and that it has a consequence of a deep interest in postcolonial discourse initially stemmed from hegemonic authority and powers" (84).

Similarly, Doro carries out this hegemony in Wild Seed. He is braggart of his powerful actions: "No." It was not fear. What was it? A lifetime of concealment, of commanding herself never to play with her abilities before others, never to show them off as mere tricks, never to let her people or any people know the full extent of her power unless she were fighting for her life" (8). He has the ability to exploit the other people for his benefit: "Should she break her tradition now simply because this stranger asked her to? He had done much talking, but what had he actually shown her about himself? Nothing" (8). Doro's powers are compared to supernatural powers: "He was like an ogbanje, an evil child spirit born to one woman again and again, only to die and give the mother pain. A woman tormented by an ogbanje could give birth many times and still have no living child. But Doro was an adult. He did not enter and re-enter his mother's womb. He did not want the bodies of children. He preferred to steal the bodies of men" (8).

Doro's powers are initiated from a hegemonic authority. This is because hegemony has a "view which even the ex-colonizers would dare to express, by saying, for example, that the colonized are like monkeys pleading for evolution. However, despite the arrogant attitude that reveals hegemony tormented relations with the roots and the insecurities of the colonizers. These colonizers mobilize the territory between center and the colonized periphery, indelibly changing the view on both, and therefore substantially contributing to the colonial suppression" (Wainwright 112). This suppression has a "status of marginality. It is a booming field that addresses common preoccupations arising from the process of decolonization and the search for alternative national and cultural identities. In this book the term colonialism will be embraced as an overall category in order to analyze different postcolonial conditions within the same framework" (112). Accordingly, it has the "politics of hegemonic fragmentation which is emphasized in order to avoid the risk of totalization and homogenization that is endemic to the postcolonial discourse. This perspective allows, for example, to compare different postcolonial traditions such as the Anglo-Indian and the Afro-Italian while respecting their specificity, while addressing crucial suppressive authorities" (113).

The "totalization" of hegemonic authorities is Doro's powerful domination in his colony: "Doro was always in a good mood after changing bodies-especially when he changed more than once in quick succession or when he changed to one of the special bodies that he bred for his use. This time, his pleasurable feelings were still with him when he reached the coast. He noticed that Anyanwu had been very quiet, but she had her quiet times" (25). Doro suppresses Anyanwu to make her breed for his colony: "And she had just seen a thing that was new to her. Doro knew people took time to get used to his changes. Only his children seemed to accept them naturally". He was willing to give Anyanwu all the time she needed" (25). Doro's willingness to breed children reflects his covetous aspiration to make his colony strong: "There were slavers on the coast. An English factor lived there, an employee of the Royal African Company, and incidentally, Doro's man. Bernard Daly was his name. He had three black wives, several half-breed children, and apparently, strong resistance to the numerous local diseases. He also had only one hand. Years before, Doro had cut off the other" (25).

Hegemony, "historically speaking" is "the term which postcolonialism refers to the consciousness arising after colonization from the entities that were once colonized and are now independent. These entities engage in subversive, resistant politics that call for the preservation of difference 
Ogaili, T. A. J. A., \& Babaee, R. (2016). Ambivalent colonal relations in octavia butler's wild seed. International Journal of Human Sciences, 13(1), 22-31. doi:10.14687/ijhs.v13i1.3458

rather than assimilation to the colonizers. Assimilation represents a transcultural fusion modeled on the dominant cultural patterns" (Chibber 119). These patterns are the colonial suppression which "implies the reversion of the role of the postcolonial from an object that is scrutinized and spoken for into a subjective role in which the postcolonial represents the colonized and the colonizer and speaks back" (119). Notwithstanding this, "there is no consensus as to when this postcolonial consciousness historically started, be- fore or after independence, or whether this is an accurate term to describe the condition of so many hegemonic entities did not share the same colonizer. These entities, in fact, use different imposed authorities, are located in different geographical areas, differ in race, ethnicity and sex, and vary in their opportunities for migration" (119).

These races are depicted in Wild Seed. It is the contact between the blacks and the whites: "The man stopped, frowned in confusion and surprise. "Who are you?" he demanded. "Who . . . what do you want here?" He was not afraid. He did not know Doro. He merely assumed he had made a mistake. He stood peering up at the tall black man and projecting hostility" (26). It is also the friendship relationships among the people of Doro's colony: "I'm a friend of Bernard Daly," Doro said. "I have business with him." Doro spoke in English as did the slaver and there was no doubt that the man understood him. Thus, when the slaver continued to stare, Doro started past him, walked toward the branding where he could see Daly talking with someone else" (26).

The concept of hegemony "can be damaging when the mannerism of terminology obfuscates the colonial strategy of a group with a weaker cultural identity, as in the case of colonial phegemonic authorities. To avoid an improper use of postcolonial discourse, it is important not to divert the attention from the historical specificities of hegemony which create its complexities and its riveted paradoxes" (Krishna 98). Furthermore, the tangible reality of "colonialism requires a quick reorientation of the postcolonial critique towards the forces of capitalism that subsume geographical peripheries and market difference as a new unfamiliar colonial suppression" (98). Here, the self-celebratory character of "hegemony innovative force often leads instead to the use of a highly inflated jargon that is obscure not only to people within the field, but also to those subaltern subjects who are supposedly the main agents of the whole postcolonial enterprise" (98). Being so, it is the "last aspect of hegemony in which the huge gap between suppressive discourse and the 'postcolonial narratives,' has provoked most of the reiterated reprimands against the legitimacy of postcolonial poetics, whose high level of theoretical sophistication often leads to frustration even among its proselytes" (102).

This frustration is caused by Doro's hegemonic authority in Wild Seed. People of his colony suffer from the lack of business: "Daly had been back in business. Doro sent him black traders who sold him slaves and his company sent him white traders who bought them. "Someone else would set up a factory here if you left," Doro told him" (32). Additionally, they are not able to make any trade: "I can't stop the trade even where it might touch my people, but I can control it." So much for his control. Neither his support of Daly nor his spies left along the coast-people who should have reported to Daly - had been enough. Now they were useless. If they had been special stock, people with unusual abilities, Doro would have resettled them in America, where they could be useful. But they were only ordinary people bought by wealth or fear or belief that Doro was a god" (32). This is because of Doro's suppressive authority: "He would forget them. He might forget Daly also once he had returned to Anyanwu's homeland and sought out as many of her descendants as he could find. At the moment, though, Daly could still be useful — and he could still be trusted; Doro knew that now. Perhaps the seed people had been taken to Bonny or New Calabar or some other slave port, but they had not passed near Daly" (32). Doro's power controls everything in the colony: "The most talented and deceptive of Doro's own children could not have lied to him successfully while he was on guard. Also, Daly had discovered he enjoyed being an arm of Doro's power" (32). This authority leads to the ambivalent relationship between Doro and his people. It is argued that 
Ogaili, T. A. J. A., \& Babaee, R. (2016). Ambivalent colonal relations in octavia butler's wild seed. International Journal of Human Sciences, 13(1), 22-31. doi:10.14687/ijhs.v13i1.3458

the hegemonic power is reconciled with ambivalence relationship on the premise of equality. Therefore, ambivalence is going to be discussed in the following section.

\section{Ambivalence}

In Wild Seed, the ambivalent relationship appears among Doro's colony people regardless their identities and colors: "This time, though, before she thought of anything that might be useful, a white man came to her, bringing a small metal container full of some liquid. The man looked at Okoye, then nodded and put the container into Anyanwu's hands" (37). These people interact with each other as if they are one nation: "He [Doro] made signs to indicate that she should get Okoye to drink. Anyanwu looked at the container, then sipped from it herself. She would not give anyone medicine she did not understand. The liquid was startlingly strong stuff that first choked her, then slowly, pleasantly warmed her, pleased her" (37). These people also help and support each other: "It was like palm wine, but much stronger. A little of it might make Okoye forget his misery. A little more might make him sleep. It was no cure, but it would not hurt him and it might help" (37).

In Nation and Narration (1990), Bhabha argues that ambivalence "might anticipate both the anger and the frustration of the colonial powers. It is a realization of the power of colonial discourse on the one hand, and its inherent confusion on the other. Unfortunately, however, at the time when colonization is increasing the necessary tools that colonialism has devised much later, to conclusively deconstruct this kind of ambivalence. It is powerlessness to take advantage of this theoretical aporia" (28). Furthermore, it is set "within imperial paradigms and hence situate the problem of representation on a separate plane altogether. It realizes the moment but cannot seize it because of the ultimately traditional framework that it works within" (30). It also "constructs and cancels, deconstructs and re-constructs at ease, thereby playing the game of representation on a plane completely removed from colonialism. Here is something we need to understand from the point of view of colonial location. There is much less anxiety about his location than in the ambivalent relations" (42).

The colonial ambivalence is the symbiosis between the blacks and the whites in Wild Seed. It is also between Anyanwu and other women: "Then she looked up and saw that the thin crewman was still there. He was a green-eyed man with a head that was too long and bones that seemed about to break through his splotchy, unshaven brown skin. He was a white man, but the sun had parched him unevenly and he looked diseased" (50). The difference between the blacks and the whites are no longer on the basis of color, instead, it is on the friendship: she would willingly avoid him if he would only leave. He had brought her Isaac. Now, he should go away and let her give the boy what care she could. In the back of her mind, she wondered over and over what could be wrong with a boy who could speed great ships through the water" (50).

In The Location of Culture (1994), Bhabha takes up the same trope of representing the colonial ambivalence. He claims that ambivalence is a "stereotype which locates itself out of the political into the psychological. It tries to identify the problem of racial segregation in terms of the equality" (109-10). The concept ambivalence has a "latent indication of colonialism. It has an imaginary conceptualization of suppression aggressivity. The subject of this latent difference from the suppression and a consequent feeling of superiority, the aggressivity masks this difference in terms of the politics of identity with the colonized people" (Young 96). Furthermore, the "identity of the colonizer is thus qualified by both fixity and fantasy-the fixity of a monolithic image of the colonized subject to dominate, compare, or identify with, as also the fantasy of the narcissistic pleasure of superiority. Both these functions of the imaginary conceptualization of equality therefore need the stereotype as an imperative" (Nandy 103). 
Ogaili, T. A. J. A., \& Babaee, R. (2016). Ambivalent colonal relations in octavia butler's wild seed. International Journal of Human Sciences, 13(1), 22-31. doi:10.14687/ijhs.v13i1.3458

This ambivalent stereotype is exemplified in Doro's character in Wild Seed. It is his brutal suppressive practices against his people: "He was still semiconscious. His eyes were closed now, but she could see that they moved under the lids. And his lips moved, formed silent words. He had almost a black man's mouth, the lips fuller than those of the other whites she had seen. Stiff yellow hairs grew from his face, showing that he had not shaved for a while" (52). He treats Anyanwu in the same suppressive way: "He had a broad, square face not unattractive to Anyanwu, and the sun had burned him a good, even brown. She wondered what white women thought of him. She wondered how white women looked" (52).

Here ambivalence is a dynamic of equality between the colonized and the colonizer in terms of representation. "We need not overemphasize the possibilities of such equality, but the movement out of the political into the psychological or the imaginary conceptualization of ambivalence which can at least ensure a pluralistic, uncertain, ambivalent framework for the construction of identity" (Appleby 68). Ambivalence "has taken this technique of disruption to new heights. It exerted the unique ideas of mimicry and hybridity which have not only challenged the colonial discursivity, but have also finally consolidated the position of the colonized entities" (Hollway 90). Accordingly, ambivalence discursive insights have a truly postcolonial aspect of equality neatness which he undertakes this ambivalent enterprise of both the colonized and the colonizer. It is cleverly camouflaging the agenda of location within a well established discourse on colonialism and its critique" (Berman 107). At the end of Wild Seed, there is an ambivalent relationship between Doro, Anyanwu, and other people. In fact, the ambivalent relationship between the colonized and the colonizer reconciles the colonial discrepancy among them. It provides a solution to the hostile encounter and suppression initiated between the colonized and the colonizer.

\section{References}

Ahmad, A. (1992). In Theory: Class, Nations, Literature. London: Verso, 1992.

Appleby, R S. (2000). The Ambivalence of the Sacred: Religion, Violence, and Reconciliation. Lanham, MD: Rowman \& Littlefield Publishers

Ashcroft, B. and Pal A. (1999). Edward said: Paradox of Identity. London: Routledge.

Berman, N., Euan M., and E. Jouannet. (2011). Passion and Ambivalence: Colonialism, Nationalism, and International Law. Leiden: BRILL

Bhabha, H. K. (1990). Nation and Narration. London: Routledge. The Location of Culture. London: Routledge, 1994.

Boehme, E. (2006). Empire, the National, and the Postcolonial. New York: Oxford University Press

Butler, O. E. (1980). Wild Seed. Garden City, N.Y: Doubleday

Chibber, V. (2012). Postcolonial Theory and the Specter of Capital. London : Verso

Hollway, W. and B. Featherstone (1997). Mothering and Ambivalence. London: Routledge,

Hoogvelt, A. (2001). Globalization and the Postcolonial World. London: Pulgrave

Kapoor, I. (2008). The Postcolonial Politics of Development. London: Routledge

Krishna, S. (2009). Globalization and Postcolonialism: Hegemony and Resistance in the Twenty-First Century. Lanham, Md: Rowman \& Littlefield Pub.

Laitin, D. (1986). Hegemony and Culture: Politics and Religious Change Among the Yoruba. Chicago: University of Chicago Press. 
Ogaili, T. A. J. A., \& Babaee, R. (2016). Ambivalent colonal relations in octavia butler's wild seed. International Journal of Human Sciences, 13(1), 22-31. doi:10.14687/ijhs.v13i1.3458

Loomba, A. (1998). Colonialism and Postcolonialism. New York: Routledge

Moore-Gilbert, B. (1997). Postcolonial Theory: Contexts, Practices, Politics. New York: Verso.

Nandy, A. (1988). The Intimate Enemy: Loss and Recovery of Self under Colonialism. New Delhi: Oxford University Press

Said, E. (1978). Orientalism. New York: Pantheon Books

Sheffer, G. (1986). Modern Diasporas in International Politics. London and Sydney: Croom Helm

Wainwright, J. (2008). Decolonizing Development: Colonial Power and the Maya. Malden, MA: Blackwell Pub.

Williams, P. \& Chrisman, L. (1994). Colonial Discourse and Post-colonial: A Reader. New York: Columbia University Press

Wisker, G. (2007). Key Concepts in Postcolonial Literature. New York: Palgrave

Young, R. (1993). White Mythologies: Writing History and the West. London: Routledge 